\title{
TINGKAT KECUKUPAN ZAT GIZI DAN KADAR GLUKOSA DARAH PADA ATLET SEPAKBOLA
}

\author{
Tri Andianne Putri, Enny Probosari*) \\ *) Program Studi Ilmu Gizi Fakultas Kedokteran Universitas Diponegoro \\ Jln. Prof. H. Soedarto, SH., Semarang, Telp (024) 8453708, Email : gizifk@ undip.ac.id
}

\begin{abstract}
Background: Athlete's performance depends on the adequacy of nutritional intake. A good food management before training can affect blood glucose level during exercise.

Objective: To determine the nutrition intake adequacy and blood glucose level in athlete

Methods: This cross-sectional study was conducted on football athlete aged 15-18 y.o at Salatiga Training Centre. The selection of 30 subjects was performed by total sampling technique. Data collected includes: identity, weight, height, body fat percentage, food intake history, and blood glucose level before and after exercise. Data were analyzed by description analysis, bivariate using Pearson correlation test, and multivariate using linear regression test.

Results: All subjects (100\%) had a normal nutritional status according to BMI/U. The mean intake of carbohydrate, protein, and fat subjects respectively $325 \mathrm{~g} \pm 7.9,89.5 \mathrm{~g} \pm 1.73,101 \mathrm{~g} \pm 2.54$. A total of $100 \%$ subjects had a normal blood glucose level before training, 96,7\% had a normal blood glucose level after training, and 3,3\% had a hypoglicemic. There is a correlation between carbohydrate and protein adequacy with blood glucose level before training $(p<0.05)$ and changes of blood glucose level during training $(p<0,05)$. There is a correlation between carbohydrate, protein, and fat adequacy with blood glucose level after training $(p<0,05)$. Variable that affect the blood glucose levels before, after exercise, and changes in blood glucose level is carbohydrate adequacy.

Conclusion: There is a significant correlation between carbohydrates and protein with changes in blood glucose level. Carbohydrate adequacy is a variable that most affect blood glucose level. This relationship has a negative correlation which means if carbohydrate and protein adequacy are better, will decrease the changes in blood glucose level.
\end{abstract}

Keywords: Athlete's Nutrition Intake, Football Athletes, Blood Glucose Level

\begin{abstract}
ABSTRAK
Latar Belakang: Performa atlet tergantung pada kecukupan asupan gizinya. Pengaturan makan yang baik sebelum latihan dapat mempengaruhi kadar glukosa darah selama latihan.

Tujuan: Mengetahui tingkat kecukupan zat gizi dan kadar glukosa darah pada atlet sepakbola.

Metode: Penelitian dengan pendekatan cross sectional di Salatiga Training Centre, jumlah sampel 30 atlet usia 15-18 tahun, dipilih dengan total sampling. Data yang dikumpulkan meliputi: identitas, berat badan, tinggi badan, persen lemak tubuh, riwayat asupan makan, dan kadar glukosa darah sebelum dan setelah latihan. Data dianalisis dengan uji deskripsi, bivariat menggunakan pearson, dan multivariat menggunakan regresi linier.

Hasil: Semua subjek memiliki status gizi normal menurut IMT/U(100\%). Rerata asupan karbohidrat, protein dan lemak subjek berturut-turut 325g $\pm 7.9,89.5 \mathrm{~g} \pm 1.73,101 \mathrm{~g} \pm 2.54$. Sebanyak $100 \%$ subjek memiliki kadar glukosa darah sebelum latihan normal, 96.7\% memiliki kadar glukosa darah setelah latihan normal, dan 3.3\% hipoglikemia. Hasil uji hubungan yang dilakukan menunjukkan terdapat hubungan antara tingkat kecukupan karbohidrat dan protein dengan kadar glukosa darah sebelum latihan ( $p<0,05)$. Terdapat hubungan antara tingkat kecukupan karbohidrat, protein, dan lemak dengan kadar glukosa darah setelah latihan $(p<0,05)$. Terdapat hubungan antara tingkat kecukupan karbohidrat dan protein dengan perubahan kadar glukosa darah selama latihan $(p<0,05)$. Variabel yang berpengaruh terhadap kadar glukosa darah sebelum, setelah latihan, dan perubahan kadar glukosa darah adalah tingkat kecukupan karbohidrat.

Simpulan: Tingkat kecukupan karbohidrat dan protein memiliki hubungan yang signifikan dengan kadar glukosa darah. Variabel tingkat kecukupan karbohidrat merupakan variabel yang paling berpengaruh terhadap perubahan kadar glukosa darah. Hubungan ini memiliki korelasi negative yang menunjukkan bahwa semakin baik tingkat kecukupan karbohidrat dan protein maka semakin sedikit perubahan kadar glukosa darah yang terjadi selama latihan.
\end{abstract}

Kata kunci: Asupan Zat Gizi Atlet, Atlet Sepak Bola, Kadar Glukosa Darah

\section{PENDAHULUAN}

Pola makan seimbang merupakan hal yang penting untuk kesehatan baik dari sudut pandang seorang atlet atau bagi mereka yang memiliki rutinitas berolahraga untuk menjaga kebugaran tubuh. Performa seorang atlet pada saat bertanding tergantung pada kecukupan gizinya. Gizi dibutuhkan dalam kerja biologik tubuh yaitu menyediakan cadangan energi tubuh pada saat seorang atlet melakukan berbagai aktivitas fisik, misalnya pada saat latihan (training), bertanding dan saat pemulihan. ${ }^{1}$ Penyelenggaraan makanan atlet memiliki tujuan umum untuk menyelenggarakan penyediaan makanan yang memenuhi kebutuhan zat 
gizi bagi setiap kelompok cabang olahraga agar tercapai prestasi yang baik. Zat gizi yang berasal dari makanan yang diasup oleh atlet dapat menyediakan cadangan glikogen otot dan hati serta menjaga karbohidrat maupun lemak tetap tersedia dalam darah untuk digunakan oleh otot. Untuk menunjang prestasinya, atlet memerlukan zat gizi yang cukup baik kualitas maupun kuantitas. Perencanaan makanan atlet perlu diselaraskan dengan perencanaan program latihan meliputi periode persiapan, pertandingan dan transisi. ${ }^{2}$

Sepakbola merupakan olahraga yang membutuhkan energi dari proses aerobik dan anaerobik dengan proporsi hampir seimbang dan berjalan secara simultan. Pada aktivitas olahraga yang dilakukan dengan intensitas tinggi dan membutuhkan power secara cepat seperti saat berlari untuk mengejar bola, gerakan melompat, mengoper, dan menendang bola, maka metabolisme energi tubuh akan berjalan secara anaerobik melalui sumber energi yang diperoleh dari simpanan glikogen. Sedangkan saat melakukan aktivitas dengan intensitas rendah seperti saat berjalan secara aerobik maka sumber energi diperoleh dari simpanan karbohidrat, lemak dan protein. Selain itu, sepak bola membutuhkan daya tahan karena dilakukan dalam waktu yang relatif lama sehingga memerlukan oksigen dari luar tubuh. ${ }^{3-6}$

Latihan sepak bola dapat mempengaruhi kadar glukosa darah, karena tubuh membutuhkan glukosa sebagai salah satu sumber energi untuk melakukan aktivitas fisik. ${ }^{7}$ Pada saat latihan, karbohidrat dapat dipecah sebagai energi melalui mekanisme aerobik dan anaerobik. Ketersediaan glukosa darah selama latihan merupakan faktor yang berpengaruh terhadap performa atlet. Apabila kadar glukosa darah menurun, fungsi sel otak terganggu karena sel saraf tidak menyimpan karbohidrat akibatnya akan berdampak pada penurunan peforma atlet. ${ }^{8-10}$ Penurunan glukosa darah setelah melakukan aktivitas olahraga dimungkinkan karena terjadinya peningkatan sensitivitas insulin dan rendahnya jumlah produksi atau pemecahan glukosa. ${ }^{11}$

Perencanaan menu yang baik sebelum menghadapi suatu pertandingan diperlukan untuk menjaga kadar glukosa darah atlet selama pertandingan. Pemenuhan kebutuhan zat gizi pada atlet sepak bola masih kurang tepat seperti tergambarkan pada penelitian yang dilakukan terhadap atlet sepak bola remaja di Kota Pasuruan dan Makassar, disimpulkan bahwa rata - rata pemenuhan zat gizi pemain sepak bola masih kurang. ${ }^{12,13}$ Memenuhi kecukupan karbohidrat merupakan strategi utama yang dilakukan untuk menjaga daya tahan tubuh dan kemampuan taktis. ${ }^{14}$ Menurut beberapa penelitian, pemberian suplemen dengan kandungan karbohidrat, pemberian makanan dengan indeks glikemik rendah, serta menerapkan carbohydrate loading dapat membantu mempertahankan kadar glukosa darah selama latihan, serta meminimalkan tingkat kelelahan, sehingga dapat menghasilkan performa yang baik. Beberapa penelitian dilakukan untuk melihat pengaruh pemberian minuman mengandung karbohidrat terhadap kadar glukosa darah atlet selama latihan, hasilnya menunjukkan bahwa setelah pemberian minuman dengan kandungan karbohidrat, kadar glukosa darah atlet menjadi naik setelah latihan. ${ }^{15-17}$ Penelitian lainnya yang dilakukan terhadap atlet sepak bola remaja menunjukkan bahwa pada saat atlet melakukan latihan terjadi penurunan kadar glukosa darah baik bagi atlet yang diberi suplementasi minuman mengandung karbohidrat ataupun bagi atlet yang tidak diberi perlakuan, namun rata-rata perbedaan penurunan kadar glukosa darah pada kelompok yang diberi minuman berkarbohidrat lebih kecil daripada kelompok kontrol. Hal ini menunjukkan bahwa pemberian minuman berkarbohidrat dapat meminimalkan penurunan kadar glukosa darah. ${ }^{18}$ Indeks glikemik karbohidrat yang dikonsumsi juga mempengaruhi kadar glukosa darah atlet selama latihan. Sebuah penelitian menunjukkan hasil bahwa subjek yang mengonsumsi makanan dengan karbohidrat yang indeks glikemiknya rendah 3 jam sebelum pertandingan menghasilkan kapasitas ketahanan yang lebih besar, kadar glukosa darah lebih tinggi, dapat memperlambat dan menstabilkan nilai glikemik selama latihan daripada setelah mengonsumsi makanan dengan karbohidrat yang indeks glikemiknya tinggi. ${ }^{19-22}$ Berdasarkan uraian diatas peneliti ingin meneliti hubungan tingkat kecukupan zat gizi dengan kadar glukosa darah atlet. Hasil penelitian ini diharapkan dapat menunjukkan bagaimana hubungan antara tingkat kecukupan zat gizi dengan kadar glukosa darah atlet yang dapat mempengaruhi performa atlet selama pertandingan.

\section{METODE}

Penelitian ini adalah penelitian observasional dengan rancangan penelitian cross sectional study dengan ruang lingkup gizi masyarakat. Sampel dalam penelitian ini adalah semua atlet sepak bola usia 15 18 tahun di Asrama Salatiga Training Center sejumlah 30 orang. Pengambilan sampel dalam penelitian ini mrnggunakan total sampling. Total sampling adalah teknik pengambilan sampel dimana jumlah sampel sama dengan populasi. Alasan memilih total sampling adalah karena jumlah populasi yang kurang dari 100 maka seluruh populasi dijadikan sampel.

Kriteria inklusi dalam penelitian ini adalah bersedia menjadi subjek penelitian yang dibuktikan dengan mengisi informed consent, berusia $15-18$ 
tahun, atlet sepak bola yang tinggal di asrama Salatiga Training Center. Kriteria eksklusi pada penelitian ini adalah subjek yang tidak menjalani semua tahap atau proses selama penelitian dilakukan dan/atau mengundurkan diri selama penelitian berlangsung.

Data yang didapatkan meliputi data identitas sampel, antropometri, asupan karbohidrat, lemak, protein, serta kadar glukosa darah sebelum dan setelah latihan. Data identitas sampel meliputi nama, tanggal lahir, usia, dan alamat . Data antropometri meliputi tinggi badan, berat badan, dan persen lemak tubuh. Data tinggi badan diperoleh dengan melakukan pengukuran menggunakan mikrotoa dengan ketelitian $1 \mathrm{~cm}$, pengukuran berat badan menggunakan timbangan digital dengan ketelitian 0,1 gram, dan persen lemak tubuh diukur menggunakan Bioelectric Impendance Analyzer (BIA) dengan merk Omron. Asupan energi, karbohidrat, lemak, dan protein diperoleh dengan menggunakan food recall 24 jam, dan data kadar glukosa darah diperoleh dari pemeriksaan glukosa darah pada saat sebelum latihan dan setelah latihan melalui pembuluh darah kapiler menggunakan alat ukur glucosemeter dengan merk Autocheck.

Status gizi subjek digambarkan dengan ZScore Indeks Masa Tubuh berdasarkan umur (IMT/U) yang diklasifikasikan menjadi 5, yaitu sangat kurus ( $z$-score $<-3 \mathrm{SD})$, kurus $(-3 \mathrm{SD} \leq z$-score $<-2 \mathrm{SD})$, normal $(-2 \mathrm{SD} \leq z$-score $<+1 \mathrm{SD})$, gemuk $(+1 \mathrm{SD} \leq z$-score $<+2 \mathrm{SD})$, dan obesitas $(z$-score $\geq$ $+2 \mathrm{SD}$ ). Gambaran persen lemak tubuh menggunakan persentil persen lemak tubuh berdasarkan umur (PLT/U) yang diklasifikasikan menjadi 4, yaitu underfat ( $\leq$ persentil ke-2), normal (>persentil ke-2 persentil ke-85), overfat (> persentil ke-85 - persentil ke-95), dan obesitas ( $\geq$ persentil ke-95). ${ }^{23}$

Kadar Glukosa Darah dalam penelitian ini dikategorikan menjadi tiga yaitu hipoglikemia, normal, dan hiperglikemia. Kadar glukosa darah dinyatakan hipoglikemia jika kadar glukosa darah $<70 \mathrm{mg} / \mathrm{dL}$, dinyatakan normal jika berkisar antara 70 - $199 \mathrm{mg} / \mathrm{dL}$, dan dinyatakan hiperglikemia jika kadar glukosa darah sewaktu $>199 \mathrm{mg} / \mathrm{dL} .^{24}$

Tingkat kebutuhan karbohidrat, protein, dan lemak atlet diperoleh dari persentase dari kebutuhan energi atlet yang diperoleh dengan menggunakan rumus kebutuhan energi atlet berdasarkan buku pedoman gizi olahraga dari Kementrian Kesehatan Republik Indonesia (Kemenkes RI) yang dihitung dengan memperhatikan beberapa komponen yaitu energi Basal Metabolic Rate (BMR), Specific Dynamic Action (SDA), Aktivitas Fisik, Energy Expenditure untuk setiap jenis dan lama latihan. Asupan karbohidrat, protein, lemak pada penelitian ini dibagi menjadi tiga kategori, yaitu kurang, cukup, dan lebih. Kategori asupan karbohidrat, protein, dan lemak kurang apabila asupan $<80 \%$ dari kebutuhan, dikatakan cukup apabila asupan 80\% - 100\% dari kebutuhan, dan dikatakan lebih apabila asupan $>100 \%$ dari kebutuhan.

Analisis deskriptif digunakan untuk melihat gambaran karakteristik subjek. Analisis bivariat diawali dengan uji normalitas data dengan uji Saphiro-Wilk. Analisis data uji hubungan menggunakan uji korelasi Pearson. Analisis multivariat menggunakan uji regresi linier.

\section{HASIL}

\section{Karakteristik Subjek Penelitian}

Subjek penelitian adalah 30 atlet sepakbola di asrama Salatiga Training Center dan mengikuti penelitian dari awal sampai akhir penelitian. Distribusi karakteristik subjek dapat dilihat pada tabel 1. Terdapat $7(23.3 \%)$ atlet berusia 15 tahun, 15 $(50 \%)$ atlet berusia 16 tahun, $6(20 \%)$ atlet berusia 17 tahun, dan sisanya yaitu $2(6.7 \%)$ atlet berusia 18 tahun. Distribusi frekuensi status gizi berdasarkan IMT/U menunjukkan bahwa $30 \quad(100 \%)$ atlet memiliki status gizi normal.

\section{Kadar Glukosa Darah, Tingkat Kecukupan Tingkat Kecukupan Karbohidrat, Protein, dan Lemak}

Rerata kadar glukosa darah sebelum latihan, setelah latihan, dan perubahan kadar glukosa darah selama latihan berturut - turut adalah 105.6 \pm 8.29 , 85.3 $\pm 9.07,20.2 \pm 5.0$. Rerata asupan karbohidrat, protein, dan lemak subjek berturut - turut adalah $325 \mathrm{gr} \pm 7.9$, 89.5gr \pm 1.73 , dan $101 \mathrm{gr} \pm 2.54$. Rerata kadar glukosa darah dan asupan dapat dilihat pada tabel 2 .

Distribusi kadar glukosa darah sebelum dan setelah latihan, serta tingkat kecukupan karbohidrat, protein, dan lemak dapat dilihat pada tabel 3. Semua subjek penelitian yaitu $30(100 \%)$ memiliki kadar glukosa darah sebelum latihan normal. Sebanyak 29 (96.7\%) atlet memiliki kadar glukosa darah setelah latihan normal, dan hanya 1 (3.3\%) atlet yang memiliki kadar glukosa darah setelah latihan yang termasuk hipoglikemia. Sebanyak 27 (90\%) atlet memiliki tingkat kecukupan karbohidrat yang kurang, dan sisanya yaitu $3(10 \%)$ atlet memiliki tingkat kecukupan karbohidrat yang cukup. Sebagian besar tingkat kecukupan protein atlet termasuk kurang yaitu sebanyak $26(86,7 \%)$ atlet, terdapat $3(10 \%)$ atlet dengan tingkat kecukupan protein cukup, dan 1 $(3,3 \%)$ atlet memiliki tingkat kecukupan protein yang lebih. Sebagian besar atlet memiliki tingkat kecukupan lemak yang lebih, yaitu 24 (80\%) atlet, 5 $(16,7 \%)$ atlet memiliki tingkat kecukupan lemak yang cukup, dan sisanya yaitu $1(3,3 \%)$ atlet memiliki tingkat kecukupan lemak yang kurang. 
Tabel 1. Distribusi Karakteristik Subjek

\begin{tabular}{lcc}
\hline \multicolumn{1}{c}{ Variabel } & n & Presentase (\%) \\
\hline Usia & 7 & 23.3 \\
15 tahun & 15 & 50 \\
16 tahun & 6 & 20 \\
17 tahun & 2 & 6.7 \\
18 tahun & & \\
Status Gizi & 0 & 0 \\
Sangat Kurus & 0 & 0 \\
Kurus & 30 & 100 \\
Normal & 0 & 0 \\
Gemuk & 0 & 0 \\
Obesitas & & \\
Persen Lemak Tubuh & 0 & 0 \\
Underfat & 28 & 93.3 \\
Normal & 2 & 6.7 \\
Overfat & 0 & 0 \\
Obesitas & & \\
\hline
\end{tabular}

Tabel 2. Distribusi Kadar Glukosa Darah, dan Asupan Karbohidrat, Lemak, Protein

\begin{tabular}{lll}
\hline Variabel & N & Mean \pm SD \\
\hline Kadar Glukosa Darah Sebelum Latihan & 30 & $105.6 \pm 8.29$ \\
Kadar Glukosa Darah Setelah Latihan & 30 & $85.3 \pm 9.07$ \\
Perubahan Kadar Glukosa Darah & 30 & $20.2 \pm 5.03$ \\
Karbohidrat (g) & 30 & $325 \pm 7.9$ \\
Protein (g) & 30 & $89.5 \pm 1.73$ \\
Lemak (g) & 30 & $101 \pm 2.54$ \\
\hline
\end{tabular}

Tabel 3. Distribusi Kadar Glukosa Darah SebelumLatihan, Setelah Latihan, dan Tingkat Kecukupan Karbohidrat, Protein, dan Lemak

\begin{tabular}{lcc}
\hline \multicolumn{1}{c}{ Variabel } & Frekuensi (n) & Presentase (\%) \\
\hline Kadar Glukosa Darah Sebelum Latihan & 0 & 0 \\
Hipoglikemia & 30 & 100 \\
Normal & 0 & 0 \\
Hiperglikemia & 1 & 3.3 \\
Kadar Glukosa Darah Setelah Latihan & 29 & 96.7 \\
Hipoglikemia & 0 & 0 \\
Normal & & \\
Hiperglikemia & 27 & 90 \\
Tingkat Kecukupan Karbohidrat & 3 & 10 \\
Kurang & 0 & 0 \\
Cukup & & \\
Lebih & 26 & 86,7 \\
Tingkat Kecukupan Protein & 3 & 10 \\
Kurang & 1 & 3,3 \\
Cukup & & 3,3 \\
Lebih & 1 & 16,7 \\
Tingkat Kecukupan Lemak & 5 & 80 \\
Kurang & 24 & 100 \\
Lukup & 30 & \\
\hline Total & & \\
\hline
\end{tabular}




\section{Analisis Bivariat}

Hasil uji korelasi antara tingkat kecukupan karbohidrat, protein, dan lemak dengan kadar glukosa darah sebelum latihan menunjukkan bahwa terdapat hubungan yang signifikan antara tingkat kecukupan karbohidrat dengan kadar glukosa darah sebelum latihan $(p=0,001)$ dan tingkat kecukupan protein dengan kadar glukosa darah $(p=0,02)$. Sedangkan tidak terdapat hubungan yang signifikan antara tingkat kecukupan lemak dengan kadar glukosa darah sebelum latihan $(p=0,095)$.

Hasil uji korelasi antara tingkat kecukupan karbohidrat, protein, dan lemak dengan kadar glukosa darah setelah latihan menunjukkan bahwa terdapat hubungan yang signifikan antara tingkat kecukupan karbohidrat, protein, dan lemak dengan kadar glukosa darah setelah latihan $(p<0,05)$.
Hasil uji korelasi antara tingkat kecukupan karbohidrat, protein, dan lemak dengan perubahan kadar glukosa darah menunjukkan bahwa terdapat hubungan yang signifikan antara tingkat kecukupan karbohidrat dengan perubahan kadar glukosa darah $(p=0,008)$ dan tingkat kecukupan protein dengan perubahan kadar glukosa darah $(p=0,013)$ yang memiliki kekuatan korelasi sedang $(\mathrm{r}=0,4-0,6)$ dan arah korelasi negatif. Artinya semakin tinggi tingkat kecukupan karbohidrat dan protein maka semakin rendah angka perubahan kadar glukosa darah. Tidak terdapat hubungan yang signifikan antara tingkat kecukupan lemak dengan perubahan kadar glukosa darah $(p=0,365)$. Hasil uji korelasi pearson antara tingkat kecukupan karbohidrat, protein, dan lemak dengan kadar glukosa darah sebelum latihan, setelah latihan, dan perubahan glukosa darah dapat dilihat pada tabel 4 .

Tabel 4. Hubungan antara Tingkat Kecukupan Karbohidrat, Protein, dan Lemak Dengan Kadar Glukosa Darah Atlet

\begin{tabular}{|c|c|c|c|c|c|c|}
\hline \multirow[t]{2}{*}{ Variabel } & \multicolumn{2}{|c|}{$\begin{array}{c}\text { Kadar Glukosa } \\
\text { Darah } \\
\text { Sebelum Latihan } \\
\end{array}$} & \multicolumn{2}{|c|}{$\begin{array}{c}\text { Kadar Glukosa } \\
\text { Darah } \\
\text { Setelah Latihan } \\
\end{array}$} & \multicolumn{2}{|c|}{$\begin{array}{c}\text { Perubahan Kadar } \\
\text { Glukosa Darah } \\
\text { Selama Latihan } \\
\end{array}$} \\
\hline & $\mathbf{r}$ & $p$ & $\mathbf{r}$ & $p$ & $\mathbf{r}$ & $p$ \\
\hline Karbohidrat & 0,57 & $0,001 *$ & 0,807 & $0,000 *$ & $-0,473$ & $0,008^{*}$ \\
\hline Protein & 0,42 & $0,020 *$ & 0,643 & $0,000 *$ & $-0,448$ & $0,013^{*}$ \\
\hline Lemak & 0,31 & 0,095 & 0,377 & $0,040 *$ & $-0,171$ & 0,365 \\
\hline
\end{tabular}

$* \mathrm{p}$ value $<0.05$

\section{Analisis Multivariat}

Variabel yang berpengaruh terhadap kadar glukosa darah sebelum latihan, kadar glukosa darah setelah latihan, dan nilai perubahan kadar glukosa darah adalah tingkat kecukupan karbohidrat. Koefisien korelasi karbohidrat dengan kadar glukosa darah sebelum latihan adalah 0,575 dengan Adjusted $R$ Square sebesar 30,7\%, artinya karbohidrat mampu menjelaskan kadar glukosa darah sebelum latihan sebesar $30,7 \%$. Sebesar $69,3 \%$ sisanya, dijelaskan oleh protein. Koefisien korelasi karbohidrat dengan kadar glukosa darah setelah latihan adalah 0,807 dengan Adjusted $R$ Square sebesar 63,9\%, artinya karbohidrat mampu menjelaskan kadar glukosa darah setelah latihan sebesar 63,9\%. Sebesar 36,1\% sisanya, dijelaskan oleh protein dan lemak. Koefisien korelasi karbohidrat dengan perubahan kadar glukosa darah selama latihan adalah -0,473 dengan Adjusted $R$ Square sebesar $19,6 \%$, artinya karbohidrat mampu menjelaskan perubahan kadar glukosa darah selama latihan sebesar 19,6\%. Sebesar 80,4\% sisanya, dijelaskan oleh protein.

\section{PEMBAHASAN}

Subjek dalam penelitian ini merupakan atlet Salatiga Training Center yang berusia 15 - 18 tahun sebanyak 30 subjek. Semua subjek dalam penelitian ini memiliki status gizi normal menurut IMT/U, sedangkan persen lemak tubuh sebagian besar subjek termasuk dalam kategori normal. Terdapat dua subjek yang memiliki kategori persen lemak tubuh overweight. Kedua subjek ini memiliki status gizi yang normal menurut IMT/U namun hampir mendekati 1SD. Persen lemak tubuh dan massa otot berhubungan dengan simpanan glikogen. Semakin sedikit persen lemak tubuh dan semakin besar massa otot, maka semakin besar pula simpanan glikogen dalam tubuh. ${ }^{3}$ Simpanan glikogen dalam otot tidak mempengaruhi kadar glukosa dalam darah. Simpanan glikogen dalam otot hanya untuk digunakan oleh sel tempat glikogen disimpan. Simpanan glikogen yang dapat mempengaruhi kadar glukosa darah dalam tubuh adalah simpanan glikogen dalam hati. Namun, piruvat yang terbentuk oleh glikolisis di otot dapat mengalami transaminasi menjadi alanin yang dikeluarkan oleh oto dan digunakan untuk glukoneogenesis di hati. ${ }^{25}$

Karbohidrat memegang peran penting dalam performa seorang atlet. Asupan karbohidrat yang cukup merupakan hal yang penting untuk pemulihan setelah latihan dan untuk mempertahankan cadangan karbohidrat dalam tubuh selama latihan. ${ }^{26}$ Asupan 
protein sangat penting pada masa tumbuh kembang remaja. individu yang asupan proteinnya rendah mengalami keseimbangan negatif nitrogen, yaitu lebih banyak nitrogen yang dikeluarkan dari tubuh daripada yang diserap tubuh. Pada tahap ini, jaringan tubuh, seperti otot dan hemoglobin dapat kehilangan daya tahan dan kekuatannya. ${ }^{3,27}$ Performa maksimal tidak mungkin tercapai tanpa adanya glikogen otot, namun lemak juga memberikan energi untuk latihan. Lemak merupakan zat gizi dengan nilai energi paling tinggi yaitu $9 \mathrm{kkal} / \mathrm{g}$ jika dibandingan dengan hidrat arang atau karbohidrat, protein ataupun alkohol. Lemak digunakan sebagai sumber tenaga saat istirahat dan saat latihan dengan intensitas rendahsedang. ${ }^{26}$

Sebagian besar subjek penelitian memiliki tingkat kecukupan karbohidrat, dan protein yang termasuk dalam kategori kurang dengan rerata asupan berturut - turut $325 \mathrm{~g} \pm 7.9,89.5 \mathrm{~g} \pm 1.73$, dan tingkat kecukupan karbohidrat, dan protein subjek berturutturut adalah kurang (90\%), kurang (86,7\%). Sedangkan tingkat kecukupan lemak subjek sebagian besar termasuk ke dalam kategori lebih dengan rerata asupan 101 \pm 2.54 , dengan tingkat kecukupan lebih $(80 \%)$. Berdasarkan data yang diperoleh dengan melakukan food recall, subjek penelitian memiliki kebiasaan mengkonsumsi makanan dalam porsi sedang. Subjek dalam penelitian ini cukup memperhatikan berat badannya oleh karena itu mereka tidak mengkonsumsi makanan sehari - hari dalam porsi besar. Selain itu keterbatasan uang saku juga menjadi penyebab mereka jarang mengkonsumsi makanan dari luar asrama. Rasa bosan terhadap makanan dari asrama juga menyebabkan asupan makan yang rendah pada subjek penelitian. Asupan zat gizi yang kurang juga dapat disebabkan oleh porsi makanan yang disediakan oleh asrama termasuk kecil. Kurangnya asupan energi pada subjek dikarenakan ada faktor kurangnya kesadaran subjek terhadap kebutuhan energi yang harus terpenuhi dan peranan zat gizi dalam menunjang stamina. Menurut data asupan subjek dari food recall, makanan yang dikonsumsi subjek sebagian besar diolah dengan cara digoreng atau ditumis. Sebagian subjek juga mengkonsumsi gorengan saat di sekolah. Hal tersebut dapat menjadi penyebab asupan lemak yang berlebihan pada subjek penelitian.

Kadar glukosa darah menunjukkan jumlah glukosa dalam darah. ${ }^{28}$ Glukosa dalam darah diatur oleh pelepasan glukosa ke dalam aliran darah, baik dari karbohidrat yang dicerna atau dari produksi glukosa dalam hati, dan pembuangan glukosa, atau penyerapan oleh sel. ${ }^{16}$ Pemeriksaan kadar glukosa darah dibagi menjadi pemeriksaan kadar glukosa darah sewaktu dan pemeriksaan kadar glukosa darah puasa. Kadar glukosa darah dapat diukur dengan pemeriksaan plasma vena atau darah kapiler. Pada pemeriksaan kadar glukosa darah sewaktu melalui plasma vena ataupun darah kapiler, kadar glukosa darah tergolong hipoglikemia jika kadar $<70 \mathrm{mg} / \mathrm{dL}$, normal jika kadar $70-199 \mathrm{mg} / \mathrm{dL}$, dan tergolong hiperglikemia jika kadar $\geq 200 \mathrm{mg} / \mathrm{dL}$. Sedangkan pada pemeriksaan gula darah puasa melalui plasma vena, kadar glukosa darah tergolong hipoglikemia jika kadar $<70 \mathrm{mg} / \mathrm{dL}$, normal jika kadar $70-125$ $\mathrm{mg} / \mathrm{dL}$, dan tergolong hiperglikemia jika kadar $\geq 126$ $\mathrm{mg} / \mathrm{dL}$. Dengan pengukuran kadar glukosa darah puasa melalui darah kapiler, kadar glukosa darah tergolong hipoglikemia jika $<70 \mathrm{mg} / \mathrm{dL}$, normal jika $60-99 \mathrm{mg} / \mathrm{dL}$, dan tergolong hiperglikemia jika $\geq 100 \mathrm{mg} / \mathrm{dL} .^{24}$

Dalam penelitian ini pengukuran glukosa darah dilakukan dengan pemeriksaan melalui darah kapiler menggunakan alat Glucosemeter pada saat sebelum latihan dan setelah latihan. Hasil pengukuran glukosa darah sebelum latihan menunjukkan bahwa $30(100 \%)$ atlet memiliki kadar glukosa darah antara $82 \mathrm{mg} / \mathrm{dL}-119 \mathrm{mg} / \mathrm{dL}$. Hal tersebut menunjukkan bahwa semua atlet di Salatiga Training Center memiliki kadar glukosa darah sebelum latihan normal. Kadar glukosa yang cukup sebelum latihan diperlukan sebagai cadangan energi yang digunakan selama latihan. Hasil pengukuran glukosa darah setelah latihan menunjukkan bahwa $29(96,7 \%)$ atlet memiliki kadar glukosa darah antara $70 \mathrm{mg} / \mathrm{dL}-105$ $\mathrm{mg} / \mathrm{dL}$, dan terdapat $1(3,3 \%)$ atlet yang memiliki kadar glukosa darah setelah latihan sebesar $62 \mathrm{mg} / \mathrm{dL}$. Hal tersebut menunjukkan bahwa sebagian besar atlet di Salatiga Training Center memiliki kadar glukosa darah setelah latihan normal, dan hanya 1 atlet yang mengalami hipoglikemia. Nilai perubahan kadar glukosa darah atlet adalah antara $12 \mathrm{mg} / \mathrm{dL}-34$ $\mathrm{mg} / \mathrm{dL}$. Hasil penelitian ini sejalan dengan beberapa penelitian sebelumnya yang telah dilakukan untuk melihat perubahan kadar glukosa darah setelah latihan. Menurut beberapa penelitian sebelumnya, kadar glukosa darah pada atlet yang tidak mengkonsumsi suplemen atau minuman mengandung karbohidrat, mengalami penurunan setelah latihan, namun masih dalam rentang normal, dan tidak mencapai hipoglikemia $(<70 \mathrm{mg} / \mathrm{dL}) \cdot{ }^{16,18,21,29,30}$

Penurunan kadar glukosa darah atlet setelah latihan dapat dipengaruhi oleh intensitas latihan, hormon, dan asupan sebelum latihan. Pada saat latihan, penurunan glukosa darah berhubungan dengan peningkatan glukosa transporter karena simulasi oleh hormon insulin. Selama latihan fisik akan terjadi peningkatan penggunakan glikogen otot dan glukosa darah sesuai dengan beratnya aktifitas fisik. Pada beberapa kondisi, penurunan glukosa darah dapat mencapai hingga pada tahap hipoglikemia, hal tersebut merepresentasikan 
simpanan glukosa dan glikogen yang makin berkurang. ${ }^{31}$ Asupan mempengaruhi cadangan glikogen. Selain itu, cadangan glikogen otot juga berhubungan dengan masa otot dan persen lemak tubuh. semakin sedikit persen lemak tubuh dan semakin besar massa otot, maka semakin besar pula simpanan glikogen dalam tubuh. ${ }^{8,32}$ Hormon yang mempengaruhi glukosa darah adalah hormon insulin, glukagon, epinephrine, dan kortisol. Hormon hormon tersebut berperan dalam menjaga dan mengontrol kadar glukosa dalam darah. ${ }^{28}$ Penurunan glukosa darah setelah melakukan aktivitas olahraga dimungkinkan karena terjadinya peningkatan sensitivitas insulin dan rendahnya jumlah produksi atau pemecahan glukosa. Insulin menghambat fosforilase hati, yang merupakan enzim utama yang menyebabkan terpecahnya glikogen dalam hati menjadi glukosa. Keadaan ini mencegah pemecahan glikogen yang sudah tersedia dalam sel-sel hati. Kadar glukosa darah juga dikaitkan dengan hormon glukagon, merupakan hormon yang disekresikan oleh sel-sel alfa pulau Langerhans sewaktu kadar glukosa darah turun, mempunyai fungsi yang bertentangan dengan efek insulin. Efek utama glukagon terhadap metabolisme glukosa adalah membantu pemecahan glikogen hati (glikogenolisis) dan meningkatkan proses glukoneogenesis di dalam hati, selain itu glukagon juga berperan meningkatkan glikogenolisis di dalam hati. Efek glukagon tersebut berguna dalam meningkatkan glukosa darah ${ }^{11,32}$

Salah satu faktor yang berpengaruh terhadap performa endurance dalam sepak bola adalah ketersediaan glukosa darah selama latihan atau pertandingan. Pada olahraga berdurasi lama, apabila pemenuhan karbohidrat eksogen tidak diperoleh dari konsumsi oral, maka laju pemecahan glukosa yang berasal dari glikogen hati tidak akan cukup untuk mengkompensasi pemakaian glukosa oleh otot dan jaringan lain. ${ }^{3,9}$ Sementara itu, glikogen otot menurun selama pertandingan sepak bola, bahkan sebanyak $7 \%$ serat otot hampir kehilangan semua cadangan glikogennya setelah pertandingan. ${ }^{33}$ Dalam kondisi ini, hipoglikemia dapat terjadi, di mana kadar glukosa darah turun hingga $3 \mathrm{mmol} /$ liter (setara dengan 54 $\mathrm{mg} / \mathrm{dl}) .{ }^{9}$

Asupan makan atlet sepak bola merupakan hal penting yang perlu diperhatikan selain latihan. Asupan zat gizi tidak memberikan jaminan bahwa atlet dapat meraih prestasi, tetapi apabila asupan zat gizi tidak mencukupi akan berpengaruh pula terhadap performa atlet karena atlet tidak dapat menggunakan kemampuan yang dimiliki secara maksimal meskipun program latihan yang dijalani sudah sesuai. Tingginya intensitas latihan dan jadwal pertandingan yang padat perlu didukung dengan pengaturan makan yang baik agar atlet mendapatkan asupan zat gizi yang sesuai untuk mencapai tingkat kesegaran jasmani dan status gizi yang optimal. ${ }^{34}$ Asupan zat gizi dapat mempengaruhi kadar glukosa darah atlet. Asupan yang baik diperlukan bagi atlet untuk menjaga kadar glukosa darah atlet selama latihan atau pertandingan. ${ }^{7,12,13}$ Hasil uji korelasi pearson menunjukkan bahwa terdapat hubungan yang signifikan antara tingkat kecukupan karbohidrat dan protein dengan kadar glukosa darah sebelum latihan $(p<0,05)$, namun tidak terdapat hubungan yang signifikan antara tingkat kecukupan lemak dengan kadar glukosa darah sebelum latihan $(p>0,05)$. Hasil penelitian ini menunjukkan bahwa terdapat hubungan yang signifikan antara tingkat kecukupan karbohidrat, protein, dan lemak dengan kadar glukosa darah setelah latihan $(p<0,05)$. Hasil penelitian ini menunjukkan bahwa terdapat hubungan yang signifikan antara tingkat kecukupan karbohidrat, dan protein dengan perubahan kadar glukosa darah selama latihan $(p<0,05)$. Namun, tidak terdapat hubungan yang signifikan antara tingkat kecukupan lemak dengan perubahan kadar glukosa darah selama latihan $(p>0,05)$. Hasil uji regresi linier menunjukkan bahwa variabel yang berpengaruh terhadap kadar glukosa darah sebelum latihan, kadar glukosa darah setelah latihan, dan nilai perubahan kadar glukosa darah adalah tingkat kecukupan karbohidrat.

Asupan energi terutama karbohidrat yang adekuat beberapa jam atau beberapa hari menjelang latihan dapat meminimalisasi pemecahan jaringan otot. Asupan tinggi karbohidrat dapat meningkatkan simpanan glikogen dalam hati dan otot. Sebaliknya, asupan karbohidrat yang rendah dapat menurunkan kadar glikogen. ${ }^{3}$ Tingkat asupan protein dapat mempengaruhi pemanfaatan glukosa dengan cara: 1) mempengaruhi sekresi insulin saat puasa dan postprandial; dan 2) menyediakan asam amino yang digunakan sebagai substrat dan mediator gluconeogenesis. ${ }^{35}$ Ketika asupan karbohidrat adalah $55-70 \%$ dari total kebutuhan energi, dan cukup untuk mendukung penambahan glikogen (7.4 gr karbohidrat $\left.\mathrm{kg}^{-1} \mathrm{~d}^{-1}\right)$, asupan protein sehari - hari yang melebihi RDA namun masih dalam rentan AMDR dapat berkontribusi dalam mempertahankan glukosa darah dengan menjadi substrat dalam glukoneogenesis. ${ }^{36}$ Hal tersebut sejalan dengan hasil penelitian ini yang menunjukkan bahwa tingkat kecukupan karbohidrat, dan protein berhubungan signifikan dengan kadar glukosa darah sebelum latihan.

Perubahan kadar glukosa darah yang terjadi setelah latihan tidak hanya dipengaruhi oleh asupan sebelum latihan, namun juga dipengaruhi oleh intensitas latihan, serta pengaruh hormonal. Lama latihan berpengaruh terhadap kadar glukosa darah selama latihan. Pada latihan berintensitas ringan, 
seperti 30-50\% dari VO2 maks, sumber energi utama yang digunakan adalah lemak, sehingga penggunaan karbohidrat tidak besar. Pada latihan berintensitas ringan, glukoneogenesis dapat membantu mempertahankan kadar glukosa darah di atas kadar hipoglikemia. Namun, pada latihan yang berintensitas 50-60\% dari VO2 maks atau lebih, penggunaan glikogen otot meningkat, sehingga lebih banyak glukosa darah digunakan, dan proses glukoneogenesis tidak cukup cepat untuk mengganti glikogen yang hilang. ${ }^{9}$

Asupan karbohidrat dapat mempertahankan kadar glukosa dalam darah dan menjaga ketersediaan glikogen. ${ }^{10,37-39}$ Karbohidrat menyediakan cadangan energi bagi tubuh dengan mengurangi ketergantungan pada cadangan glikogen hati dan otot untuk energi menyediakan sumber karbohidrat alternatif saat glikogen habis. ${ }^{3}$ Dalam bidang gizi olahraga, karbohidrat sudah sering dihubungkan dengan kadar glukosa darah. Beberapa penelitian yang telah dilakukan untuk melihat pengaruh karbohidrat terhadap kadar glukosa darah menunjukkan hasil bahwa pada subjek yang diberi perlakuan tambahan asupan karbohidrat dapat mempertahankan kadar glukosa darah atau meminimalkan penurunan kadar glukosa darah setelah latihan. ${ }^{15-18}$ Hal ini menunjukkan bahwa karbohidrat merupakan zat gizi yang berpengaruh terhadap kadar glukosa darah. Tubuh menggunakan karbohidrat sebagai sumber energi saat latihan. Karbohidrat yang dikonsumsi akan dipecah oleh tubuh menjadi glukosa monosakarida, yang merupakan cadangan energi dalam tubuh. Selama latihan, saat energi dibutuhkan, glukosa yang tersimpan pada otot, mengalir ke aliran darah, dan/atau disimpan di hati sehingga dapat langsung bekerja di dalam sel dan diubah menjadi ATP. Jika jumlah glukosa atau glikogen terbatas, maka akan terjadi glukoneogenesis. Dalam glukoneogenesis, akan terjadi konversi dari zat non-glukosa seperti protein atau gliserol (molekul tiga karbon) menjadi glukosa. ${ }^{3,27}$

Asupan protein berhubungan dengan masa otot, sehingga protein menjadi zat gizi yang esensial bagi atlet dan individu pada umumnya. ${ }^{3,27}$ Massa otot berhubungan dengan cadangan glikogen, semakin besar massa otot, maka semakin besar pula simpanan glikogen dalam tubuh. Protein juga memberikan struktur pada banyak bagian dalam tubuh yang dibutuhkan untuk perkembangan dan pemulihan jaringan tubuh, dan membentuk hormon yang membantu meregulasi berbagai proses dalam tubuh. ${ }^{3,27}$

Peningkatan resintesis ATP yang terjadi selama melakukan aktifitas fisik menunjukkan bahwa glikogenolisis terikat pada glikolisis anaerobik yang muncul diantara sel sitosol. Pembatasan metabolism anaerobik glikogen akan mempengaruhi kemampuan untuk mempertahankan kontraksi otot dan dapat membatasi performa dan kelelahan. Seiring dengan peningkatan durasi, intensitas aktivitas tersebut akan menurun. Tingkat resintesis ATP akan terjadi dari pemecahan zat lain seperti oksidasi aerobik glikogen, atau metabolisme asam lemak dari simpanan intramuscular trigliseride (IMTG). Selanjutnya, jika durasi aktifitas fisik lebih panjang, jalur utama pengisian ATP akan menjadi metabolisme aerobik glikogen, glukosa, dan IMTG dan asam lemak plasma yang dikeluarkan dari simpanan jaringan adiposa. Terdapat kemungkinan terdapat kontribusi yang besar dari asam amino saat aktifitas dilakukan lebih lama lagi, terutama jika terjadi kekurangan energi kronis. ${ }^{1}$

\section{SIMPULAN}

Dalam penelitian ini terdapat hubungan yang signifikan antara tingkat kecukupan karbohidrat dan protein dengan kadar glukosa darah sebelum latihan $(\mathrm{p}<0,05)$, namun tidak terdapat hubungan yang signifikan antara tingkat kecukupan lemak dengan kadar glukosa darah sebelum latihan ( $p>0,05)$. Hasil penelitian ini juga menunjukkan bahwa terdapat hubungan yang signifikan antara tingkat kecukupan karbohidrat, protein, dan lemak dengan kadar glukosa darah setelah latihan $(p<0,05)$. Hasil penelitian ini menunjukkan bahwa terdapat hubungan yang signifikan antara tingkat kecukupan karbohidrat, dan protein dengan perubahan kadar glukosa darah selama latihan $(\mathrm{p}<0,05)$. Namun, tidak terdapat hubungan yang signifikan antara tingkat kecukupan lemak dengan perubahan kadar glukosa darah selama latihan ( $p>0,05)$. Hasil uji regresi linier menunjukkan bahwa variabel yang berpengaruh terhadap kadar glukosa darah sebelum latihan, kadar glukosa darah setelah latihan, dan nilai perubahan kadar glukosa darah adalah tingkat kecukupan karbohidrat. Hubungan ini memiliki korelasi negative yang menunjukkan bahwa semakin baik tingkat kecukupan karbohidrat dan protein maka semakin sedikit perubahan kadar glukosa darah yang terjadi selama latihan.

\section{SARAN}

Asupan atlet sepak bola di asrama Salatiga Training Center sebagian besar masih tergolong dalam kategori kurang, terutama asupan karbohidrat dan protein. Walaupun kadar glukosa darah atlet sebelum latihan termasuk kategori normal, dan sebagian besar kadar glukosa darah setelah latihan juga normal, namun beberapa atlet memiliki kadar glukosa darah setelah latihan yang hampir mencapai hipoglikemia dan mengalami penurunan kadar 
glukosa darah yang cukup banyak. Perlu adanya peningkatan pemahaman dan kesadaran pada atlet mengenai aturan pola makan yang benar secara kualitas maupun kuantitas untuk mencapai gizi yang seimbang. Sebaiknya pihak asrama lebih memperhatikan kecukupan asupan gizi atlet agar lebih dapat menunjang performa yang lebih baik. Penelitian lebih lanjut dengan melakukan tes performa pada atlet perlu dilakukan untuk melihat apakah cadangan glukosa dalam darah sudah memenuhi kebutuhan atlet untuk menghasilkan performa yang baik saat latihan.

\section{UCAPAN TERIMA KASIH}

Puji syukur penulis panjatkan kepada Allah SWT yang telah memberikan berkah dan rahmatNya sehingga penulis dapat menyelesaikan karya tulis ilmiah ini. Terimakasih penulis sampaikan kepada dr. Enny Probosari, M.Si.Med sebagai pembimbing dan Prof. dr. HM. Sulchan, MSc., DA.Nutr., SpGK, dan Deny Yudi Fitranti, S.Gz., M.Si sebagai penguji atas bimbingan, saran, dan masukan yang membangun untuk karya tulis ini. Terima kasih penulis sampaikan kepada Salatiga Training Center yang telah bekerja sama dan membantu membantu terlaksananya penelitian ini. Ucapan terima kasih juga penulis sampaikan kepada keluarga, teman - teman, dan seluruh pihak yang telah membantu dan mendukung sehingga penelitian ini dapat diselesaikan.

\section{DAFTAR PUSTAKA}

1. Collins, A. et al. Sport and Exercise Nutrition. John Willey \& Sons. 2011.

2. Haryono I, dkk. Gaya Hidup, Status Gizi, dan Stamina Atlet pada Sebuah Klub Sepak Bola. Berita Kedokteran Masyarakat. 2007 Desember 4; Vol 23 (4): 192-199.

3. Fink, H, Mikesky A. Practical Applications in Sports Nutrition. 4th ed. Burlington, MA:Jones \& Bartlett Learning; 2015.

4. Direktorat Bina Gizi dan KIA. Pedoman Gizi Olahraga Prestasi. Jakarta: Kementrian Kesehatan RI. 2014.

5. Bidang Sport Science Penerapan Iptek Olahraga Komite Olahraga Nasional Indonesia (KONI). Pemahaman Dasar Sport Science dan Penerapan Iptek Olahraga. Komite Olahraga Nasional Indonesia. 2010.

6. Irianto, DP. Panduan Gizi Lengkap Keluarga dan Olahragawan. Yogyakarta: Penerbit Andi ; 2007.

7. Mc Mahon SK, et al. Glucose Requirements to Maintain Euglycemia After Moderate-Intensity Afternoon Exercise in Adolescents With Type 1 Diabetes Are Increased in A Biphasic Manner. J Clin Endocrinol Metab 2007, 92(3):963-968.

8. Heater HF, Lisa AB, Alan EM. Practical Application in Sports Nutrition. Massachusetts: Jones and Bartlett Publisher; 2006.p.82-83; 224-26; 326; 434; 470-75.

9. William MH. Nutrition for Health, Fitness, and Sport. 8th Edition. New York: Mc Graw-Hiil Companies, Inc; 2007.p.118-20; 122; 124; 125; 128; 129; 131
10. Alv A, Williams C, Nicholas CW, Foskett A. The Influence of Carbohydrate-Electrolyte Ingestion on Soccer Skill Performance. Medicine \& Science in Sports \& Exercise 2007; 3911-1969.

11. Robert K. Muray, Daryl K. Granner. Victor W Rodwell. Biokimia Harper Edisi 27. Penerbit Jakarta: Buku Kedokteran EGC; 2009 (35)

12. Penggalih MH, Huriyati E. Gaya Hidup, Status Gizi dan Stamina Atlet pada Sebuah Klub Sepakbola. Yogyakarta: Berita Kedokteran Masyarakat Vol. 23, No. 4; 2007. Hal 192 - 199

13. Veronica D, Dachlan D, Taiyeb M. Gambaran Status Gizi Antropometri dan Asupan Zat Gizi Siswa Sekolah Sepak Bola Anyelir dan Sekolah Sepak Bola Bangau Putra Makassar Tahun 2013. Makassar : Universitas Hasanuddin; 2013.

14. Fe'De'Ration Internationale De Football Association/F-Marc (2006) Nutrition for Football: The FIFA/F Marc Consensus Conference. J Sports Sci 24, 663-664

15. O'reilly J, Wong Sh. Effect Of A Carbohydrate Drink on Soccer Skill Performance Following A SportSpecific Training Program. Journal Of Exercise Science \& Fitness $11: 2013$ p. 95 - 101

16. Lurenson DM, Dubé DJ. Effects of Carbohydrate and Protein Supplementation during Resistance Exercise on Respiratory Exchange Ratio, Blood Glucose, and Performance. Journal Of Clinical \& Translational Endocrinology 2 (2015) 1-5.

17. Gomes et al. Does Carbohydrate Supplementation Enhance Tennis Match Play Performance? Journal Of The International Society of Sports Nutrition 2013 10:46

18. Rukmana, E. Pengaruh Pemberian Minuman Berkarbohidrat Sebelum Latihan Terhadap Kadar Glukosa Darah Atlet [Skripsi]. Semarang : Universitas Diponegoro; 2013.

19. Ching-Lin Wu, Clyde Williams. A Low Glycemic Index Meal before Exercise Improves Endurance Runningcapacity In Men. International Journal Of Sport Nutrition And Exercise Metabolism, 2006;16: 510-527

20. Wong, S.H.S., Siu, P.M., Lok, A. Chen, Y.J., Morris, J., \& Lam, C.W. (2008). Effect of The Glycaemic Index of Pre-Exercise Carbohydrate Meals on Running Performance. European Journal of Sport Science, 8(1), 23-33

21. Djuned, S. Pengaruh Diet Indeks Glikemik Tinggi dan Rendah terhadap Kadar Glukosa Darah Atlet Lari [Skripsi]. Semarang: Universitas Diponegoro; 2014.

22. Cocate Et Al.Metabolic Responses To High Glycemic Index and Low Glycemic Index Meals: A Controlled Crossover Clinical Trial Nutrition Journal 2011, 10:1

23. McCarthy HD, Cloe TJ, Fry T, Jebb SA, Prentice AM. Pediatric Highlight: Body Fat Reference Curves for Children. International Journal of Obesity (2006) 30, 598-602

24. Rudijanto A, Yuwano A, Shahab A, Manaf A, Pramono B, dkk. Konsensus Pengendalian dan Pencegahan Diabetes Mellitus Tipe 2 di Indonesia. Jakarta: Pengurus Besar Persatuan Endokrinologi Indonesia (PB PERKENI); 2015. 
25. Gropper Sareen S, et all. Advanced Nutrition and Human Metabolism Fifth Edition. Belmont: Wadsworth; 2009.

26. Dorfman L. Nutrition for Exercise and Sports Performance, in: Mahan LK, Escott-Stump S, editor. Krause's Food and Nutrition Therapy. 13th ed. Philadelphia : Saunders Elsevier, Inc ; 2012. p. 507 18.

27. Muth, ND. Sports Nutrition for Health Professionals. Philadelphia: F.A Davis Company; 2015.

28. Matthew L. Goodwin. blood Glucose Regulation during Prolonged, Submaximal, Continuous Exercise: A Guide for Clinicians. 2010; 4(3) 694-702.

29. Utoro, BF. Pengaruh Penerapan Carbohydrate Loading Modifikasi terhadap Kesegaran Jasmani Atlet Sepak Bola [Skripsi]. Semarang: Universitas Diponegoro; 2011.

30. Hasegawa-Tanaka, Machida S, Kobayashi S, Naito H. Changes in Blood Glucose and Lipid Metabolic Parameters after High-Carbohydrate Diet Ingestion in Athlete with Insulin Resistance. Japan: Graduate School of Health and Sport Science, Juntendo University; 2016.

31. Kurniasari L. Pengaruh Latihan Aerobik Intensitas Sedang terhadap Kadar Glukosa Darah pada Pasien Diabetes Melitus Tipe 2 Di Desa Langensari Kabupaten Semarang [Skripsi]. Semarang: STIKES Ngudi Waluyo; 2014.

32. Guyton C, Hall JE. Buku Ajar Fisiologi Kedokteran. Edisi 11. penerbit Buku Kedokteran: 2007.

33. Krustrup P, Mohri M, Steensberg A, Bencke J, Kjaer M. Muscle and blood metabolites during a soccer game: implications for sprint performance. Med. Sci. Sports Exerc 2006; 10:1

34. Irawan MA. Nutrisi, energi dan performa olahraga. Polton Sports Science and Performance Lab: 2007

35. Millward DJ, Layman DK, Tome D, Schaafsma G: Protein quality assessment: impact of expanding understanding of protein and amino acid needs for optimal health. Am J Clin Nutr 2008, 87:1576S-1581S.

36. Pasiakos et al.: Level of dietary protein intake affects glucose turnover in endurance-trained men. Journal of the International Society of Sports Nutrition 2011 8:20.

37. Kreider RB, Wilborn CD, Taylor L, et al. ISSN Exercise \& Sport Nutrition Review: Research \& Recommendations. J Int Soc. Sport Nutr. 2011;7:7.

38. Bird SP, Tarpenning KM, Marino FE. Effects of liquid carbohydrate/essential amino acid ingestion on acute hormonal response during a single bout of resistance exercise in untrained men. Nutrition 2006;22(4):367e75.

39. Ali A, Williams C. Carbohydrate ingestion and soccer skill performance during prolonged intermittent exercise. J Sports Sci. 2009;27:1499e1508. 